UDC 378.147

DOI: $10.31470 / 2415-3729-2019-9-226-243$

\title{
Features of Using «Flipped Learning» Technology in Higher Education Institutions
}

\section{Olha Shapran}

Doctor of Pedagogy, Professor,

Head of the Department of Pedagogy

Pereiaslav-Khmelnytskyi Hryhorii Skovoroda State

Pedagogical University,

$\bowtie$ 30, Sukhomlynskyi Str., Pereiaslav-Khmelnytskyi, Kyiv

Region, Ukraine, 08401

E-mail: olia.shapran@gmail.com

ORCID: 0000-0002-7514-6632

\section{Oleksii Shapran}

Student of the Faculty of Accounting Audit and Informational

Systems («Computer Science»)

Kiev National University of Commerce and Economics,

Kiev, Ukraine

$\triangle 19$, Kioto Str., Kyiv, Ukraine, 02156

E-mail: alexeyshapran333@gmail.com

ORCID: 0000-0003-1329-4047

Date of receipt of the article: December 04, 2018 Article accepted for publication: February 22, 2019

\section{Особливості \\ застосування \\ технологї̈ «перевернутого навчання» у закладах вищої освіти}

\section{Ольга Іллівна Шапран}

доктор педагогічних наук, професор, завідувач кафедри педагогіки

ДВНЗ «Переяслав-Хмельницький державний педагогічний університет імені Григорія Сковороди»,

$\checkmark$ вул. Сухомлинського, 30, м. Переяслав-Хмельницький, Київська обл., Україна, 08401 


\section{Олексій Юрійович Шапран}

студент факультету аудиту, бухгалтерського обліку та інформаційних систем («Комп’ютерні науки»)

Київський національний торговельно-економічний університет, $\bowtie$ вул. Кіото, 19, м. Київ, Україна, 02156

Дата надходження статті: 04 грудня 2018 р. Стаття прийнята до друку: 22 лютого 2019 р.

\section{Abstract}

The article describes the use of the «flipped learning» technology in the practice of higher education institutions. The benefit of the study is that the authors have proved that the technology of «flipped learning» is based on the ideas of active learning, involving students in joint activities and combined teaching system. This technology helps to optimize studying at higher educational institutions. The essence of this technology is that students learn the new material which is based on video lectures, presentations, or other media technologies on their own at home and the next classroom work involves discussing problem issues, consolidating theoretical knowledge and developing practical skills, assessing the absorption of new material. Moreover, this allows students to determine their own learning pace and develop individual teaching strategies. Another advantage of «flipped learning» technology is the ability to use more class time for group activities, where students can discuss the content of the lecture, check their knowledge and interact with each other in an interactive mode that promotes the development of their practical skills. It is proved that as any educational technology «inverted learning» technology is characterized by algorithmicity and a certain order of educational actions of teachers and students. For effective implementation of «flipped learning» technology, the certain cycles (phases) are used, such as a phase of viewing the educational video, a phase of interactive work; a phase of the result awareness; a feedback phase and more. Each stage requires not only student's but also teacher's activity, 
who have to develop additional training or control materials for classes. The authors have analyzed the advantages and difficulties of applying «flipped learning» technology in higher education institutions. The article outlines the features of «flipped learning» in high school (the expediency of its use in senior courses, low awareness of this technology, lack of time and the need for some adaptation to its application, low technical readiness of teachers to «flipped learning» technology) and describes the experience of using this technology in the practice of teaching «High School Pedagogy» subject for students of the Pereiaslav-Khmelnytskyi Hryhorii Skovoroda State Pedagogical University.

Key words: «inverted learning», blended learning, video lectures, coaching, learning games, electronic environment.

\section{References}

1. Antonova, N.L \& Merenkov, A.V. (2018). Model «perevernutogo obucheniya» v sisteme vyisshey shkolyi: problemyi i protivorechiya. [The model of «inverted learning» in the system of higher education: problems and contradictions]. Integratsiya obrazovaniya, 22, vol. 2, 237247 [in Russian].

2. Baida, M.V. (2015). Vykorystannia klasychnykh tekhnolohii kooperatyvnoho navchannia na zmishanykh ta perevernutykh zaniattiakh u protsesi fakhovoi pidhotovky vchyteliv-filolohiv [The use of classical cooperative teaching technologies in mixed and inverted classes in the process of teachers-philologists' professional training]. Visnyk Zhytomyrskoho derzhavnoho universytetu. Ser: Pedahohichni nauky, 4 (82), 83-87 [in Ukrainian].

3. Kademiia, M.Yu. (2017). Informatsiino-komunikatsiini tekhnolohii $\mathrm{u}$ perevernutomu navchanni studentiv [Information and communication technologies in inverted students training]. Zvitna naukova konferentsiia Instytutu informatsiinykh tekhnolohii i zasobiv navchannia NAPN Ukrainy. Kyiv : IITZN NAPN Ukrainy (pp.147-150) [in Ukrainian].

4. Kuzminska, O.H. (2016). Perevernute navchannia: praktychnyi aspekt [Inverted Learning: A Practical Aspect]. 
Informatsiini tekhnolohii v osviti. № 1 (26). S. 86-98. [in Ukrainian].

5. Popadiuk, S.S. \& Skurativska, M.O. (2017). Metodolohichni zasady vykorystannia osvitnoi kontseptsii «perevernute navchannia» u vyshchii shkoli [The methodological principles of using the educational concept of «inverted learning» in higher education]. Zb. nauk. prats Kherson ped. un-tu. Pedahohichni nauky, LXXVI, Vol. 3, 149-154 [in Ukrainian].

6. Prykhodkina,N.O. (2014). Vykorystannia tekhnolohii «perevernenoho navchannia» $u$ profesiinii diialnosti vykladachiv vyshchoi shkoly [Using the technology of «inverted learning» in the high school teachers' professional work]. Naukovyi visnyk Uzhhorod. nats. untu. Ser.: Pedahohika, sotsialna robota, 30, 141-144 [in Ukrainian].

7. Harlamova, T.V. (2014). Perevernutoe obuchenie kak novyiy stsenariy obucheniya. [Inverted learning as a new learning scenario]. Inostrannyie yazyiki $\mathrm{v}$ kontekste mezhkulturnoy kommunikatsii: mater. dokladov VI Mezhdunarod. Internet-konf. (g. Saratov, 26-28 fevralya 2014 g.). Saratov, 312-317. Retrieved from http:// www.sgu.ru/ sites/ default/files/ textdocsfiles/ 2015/02/18/ harlamova_t.v._perevernutoe_obuchenie_pf.pdf [in Russian]

8. Bergmann, J., \& Sams, A. (2012). Flip Your Classroom: Reach Every Student in Every Class Every Day. Washington DC: International Society for Technology in Education.

9. Roehl, A., Reddy, L.S. \& Shannon, G.J., 2013. The flipped classroom: An opportunity to engage millennial students through active learning strategies. Journal of Family and Consumer Sciences. Vol. 105, 2, 44-49. Retrieved from http://eric.ed.gov/?id=EJ1045858.

10. Marshall, H. (2013). Three reasons to flip your classroom. Bilingual Basics. Retrieved from http:// newsmanagercommpartnerscom tesolbeis. 
11. Sharples, M., Adams, A., Ferguson, R., Gaved, M., McAndrew, P., Rienties, B., Weller, M., \& Whitelock,D. (2014). Innovating Pedagogy 2014: Open University Innovation Report 3. Milton Keynes: The Open University.

\section{Вступ}

Освітні тенденції модернізації вищої школи України останніх років обумовлюють скорочення кількості годин в закладах вищої освіти на вивчення майбутніми фахівцями різних дисциплін. Отже, питання якісного засвоєння студентами необхідного обсягу навчального матеріалу, особливо в умовах високотехнологічного інформаційного суспільства та комп'ютерної грамотності молоді набувають вирішального значення для підготовки компетентнісного та конкурентоспроможного фахівця.

Новий погляд на систему вищої освіти актуалізує дослідження в галузі технологій навчання, а також їх застосування у практиці роботи сучасних закладів вищої освіти. Так, у доповіді Відкритого університету (Велика Британія, 2014) визначено провідні тенденції в сучасних педагогічних практиках, які б сприяли активному залученню учнів (студентів) до освітнього процесу, а саме: розвиток масового відкритого соціального навчання (Massive Open Social Learning [Massive open online course] (MOOCs)), навчального дизайну на основі аналізу даних (Learning design informed by analytics), навчання на основі подій (Event-based learning), навчання на основі розповіді історій (Learning Through Storytelling) та ін. (Sharples, Adams, Ferguson, Gaved, McAndrew, Rienties, Weller, Whitelock, 2014). Ці технології дозволяють відійти від традиційних підходів організації освітнього процесу в закладах вищої освіти, посилити практичну орієнтацію навчання, залучити студентську аудиторію до активної самостійної роботи.

Однією 3 технологій, що починає активно використовуватися у вищій школі є «перевернуте навчання» (англ. flipped learning). Засновником цієї технології вважається С. Хан (Sal Khan), який у 2005 році як аналітик 
хедж-фондів створив програму та відео інструкції для виконання математичних завдань, щоб допомогти двоюрідним братам та сестрам у навчанні на відстані. Його вправи стали дуже популярними на YouTube завдяки користувачам, серед яких був і Б. Гейтс (Bill Gates). У 2007 році цей принцип побудови програм навчання був розвинений вчителями природничих наук Дж. Бергманном (J. Bergmann) та А. Самсом (A. Sams) та запропонований учням Вудландської школи в штаті Колорадо (США). Ці вчителі запропонували короткі відеоподкасти з матеріалами лекцій, які учні мали переглядати вдома, a уроки присвячувались лабораторним роботам і відповідям на запитання учнів.

Проблема впровадження технології «перевернутого навчання» у вищій школі присвячені праці таких науковців як Н. Антонова, А. Меренков, М. Байда, М. Кадемія, О. Кузьмінська, С. Попадюк, М. Скуратівська, Н. Приходькіна, Т. Харламова та ін. Серед зарубіжних досліджень цієї проблеми виділяються наукові доробки таких дослідників як Дж. Бергманн (J. Bergmann) та А. Самс (A. Sams), А. Роел (A.Roehl), Л. Редді (L. Reddy), Г. Шеннон (G. Shannon), X. Маршалл (H. Marshall) та ін.

Проблема визначення особливостей технології «перевернутого навчання» пов'язана 3 широким іï застосуванням у вищій школі та зосередження уваги не тільки на iï перевагах, але й труднощах i недоліках впровадження у практику професійної підготовки майбутніх фахівців.

Мета статті - визначити особливості використання технології «перевернутого навчання» у вищій школі. У процесі дослідження були поставлені такі завдання: охарактеризувати технологію «перевернутого навчання»; визначити переваги та труднощі іiі впровадження у практику роботи закладів вищої освіти; описати досвід використання цієї технології з урахуванням її особливостей.

\section{Матеріал і методи досліджень}

Методи дослідження добиралися відповідно до проблематики статті, зокрема, теоретичні (аналіз та 
узагальнення психолого-педагогічної літератури), емпіричні (систематизація власного емпіричного досвіду роботи).

\section{Результати та їх обговорення}

Науковці єдині в поглядах на «перевернуте навчання» як різновиду технології змішаного навчання (blended learning), що передбачає інтеграцію традиційних форм навчання 3 елементами дистанційного навчання. Змішане навчання поєднує різні навчальні заходи, що включають очне навчання, онлайн електронне навчання і самонавчання (електронні курси, практичне навчання, робота над конкретними проектами, використання електронних книг, мобільне навчання, коучинг, навчальні ігри та симуляції тощо). Окрім того, технологія «перевернутого навчання» відноситься до технологій інтенсивного навчання, що передбачають інтенсифікацію освітнього процесу, досягнення максимуму його ефективності за короткий навчальний час, збільшення обсягу і швидкості засвоєння матеріалу студентами 3 мінімальними затратами зусиль професорсько-викладацького складу; активізацію діяльності студентів, їх психологічних резервів тощо. Отже, технологія «перевернутого навчання» сприяє оптимізації навчання у вищій школі, спирається на такі ідеї як активне навчання, залучення студентів до спільної діяльності, комбінована система навчання.

Сутність цієї технології полягає у тому, що студенти самостійно ознайомлюються з новим матеріалом у домашніх умовах на основі відео лекцій, презентацій, а наступна аудиторна робота передбачає обговорення проблемних питань, закріплення теоретичних знань і вироблення практичних навичок, оцінювання засвоєння нового матеріалу тощо. Використання відео та інших попередньо записаних інформаційних носіїв дозволяє студентам визначати власний темп навчання, виробляти індивідуальні стратегії роботи 3 навчальним матеріалом.

М. Байда зазначає, що у вищій школі особливістю технологій перевернутого навчання виступає заміна місцями лекції і практичного заняття. Провідною метою такої заміни є збільшення часу на обговорення питань на занятті та 
залучення якнайбільшої кількості студентів до навчання в кооперативних групах. Так, замість проведення лекції в класі, текстовий матеріал лекції дається на самостійне опрацювання вдома шляхом перегляду лекцій в режимі онлайн, читанням, слуханням аудіо запису лекції. Після домашнього опрацювання матеріалу студенти обговорюють опрацьований матеріал у класі в кооперативному режимі ... (Байда, 2015: 84).

Отже, цінність технології «перевернутого навчання» полягає у можливості використовувати навчальний час для групових занять, коли студенти можуть обговорювати зміст лекції, перевіряти свої знання і взаємодіяти між собою в інтерактивному режимі, що сприяє розвитку їх практичних умінь та навичок.

Н. Приходькіна доводить, що у процесі «перевернутого навчання» роль викладача - виступати тренером або консультантом, заохочуючи студентів на самостійні дослідження й спільну роботу. «Перевернуте навчання», як відмічає автор, припускає зміну ролі викладачів, які здають свої передові позиції на користь більш тісного співробітництва й спільного внеску в навчальний процес. Супровідні зміни торкаються й ролей студентів, багато з яких звикли бути пасивними учасниками в процесі навчання, який подається їм у готовому виді. Перевернута модель покладає більшу відповідальність за навчання на плечі студентів, даючи їм стимул для експериментування. Діяльність може очолюватися студентами, а спілкування між студентами може стати визначальною рушійної силою процесу, спрямованого на навчання за допомогою практичних навичок. На думку вченої, «перевернуте навчання» призводить до значного зсуву пріоритетів від простої подачі матеріалу до роботи над його вдосконалюванням (Приходькіна, 2014: 142). Отже, роль викладача в процесі використання «перевернутого навчання» на аудиторних заняттях суттєво змінюється. Він виступає як тренер, консультант, тьютор, експерт, який заохочує студентів до самостійних досліджень та спільної групової роботи, оцінює рівень їх практичних вмінь. Студенти опановують навчальний матеріал, зазвичай, на 
основі самонавчання, що сприяє розвитку їх пізнавальної активності та самостійності.

Т. Харламова зазначає, що «перевернуте навчання» має деяку схожість 3 випереджаючою самостійною роботою, коли вивчення студентами нового матеріалу здійснюється до його викладу викладачем на лекції або практичних заняттях. Основна відмінність цих видів роботи, на думку автора, полягає в тому, що у випереджаючій самостійній роботі студент самостійно здійснює пізнавально-пошукову чи творчу діяльність поза аудиторією, тоді як при «перевернутому навчанні» студент вивчає новий матеріал за допомогою комп'ютерних технологій, а викладач віртуально присутній і керує цим процесом (відео пояснення, контрольні питання) (Харламова, 2014). Таким чином, «перевернуте навчання» і випереджаюча самостійна робота мають певні відмінності, що зумовлені рівнем їх зворотного зв'язку між викладачем та студентами.

Як для любої освітньої технології «перевернутому навчанню» притаманна алгоритмічність та певний порядок навчальних дій викладачів і студентів. М. Кадемія описує етапність проведення технології перевернутого навчання: в навчальних закладах, які мають корпоративну мережу 3 виходом в Інтернет створюються освітні портали на яких розміщені електронні навчально-методичні комплекси, що містять різні матеріали (відео-лекції, лабораторні роботи, практичні і семінарські заняття зі змістом відповідних матеріалів, а також блок-моніторингу знань студентів, за допомогою якого можливо виявити рівень засвоєння навчального матеріалу). Студенти одержують можливість багаторазово переглядати навчальні матеріали, здійснювати індивідуальну самостійну роботу в електронному середовищі. Викладач контролює і коригує, перевіряє тести студентів. Інтерактивний характер вивчення навчального матеріалу забезпечується за рахунок взаємодії студентів i викладача, а також студентів між собою після спільного обговорення навчальних матеріалів. Важливим, на думку автора, є робота студентів у проектах: короткотривалих i довготривалих 3 окремих тем, а особливо інтегрованих, в 
яких інтегруються знання $з$ декількох дисциплін. Це дає можливість викладачу підбирати та реалізовувати проекти за конкретною професійною діяльністю, на основі реальних ситуацій (Кадемія, 2017: 147-149). Отже, технологія «перевернутого навчання» передбачає колективне і особисто значиме вирішення навчально-професійних задач кожним учасником освітнього процесу, починаючи з самостійного перегляду студентами відео-лекцій, обговорення основних іiі питань в аудиторії під час семінарських занять та закінчуючи контролем і корекцією знань студентів викладачами.

О. Кузьминська виділяє чотири фази у процесі організації «перевернутого» навчання: 1. Досвід. Цикл починається із залучення студентів до експериментальної діяльності, актуалізації (чи визначення) наявного досвіду, мотивації до дослідження визначеної предметної галузі та реконструкції власного знання і досвіду, встановлення зв'язків із реальним життям, визначення практичної значущості очікуваних результатів, цілепокладання тощо. 2. Дослідження (вивчення предметної галузі). Під час реалізації цієї фази студенти досліджують питання чи шукають шляхи вирішення проблем, виявлених під час проведення експериментальної діяльності. 3. Усвідомлення результату. Мета цієї фази - рефлексія студентів щодо їх діяльності та результатів, одержаних у процесі реалізації попередніх етапів. Це фаза усвідомлення результатів випробувань (фаза 1) та навчання й аналізу матеріалів від експертів (фаза 2). 4. Демонстрація $i$ застосування. На цьому етапі студенти мають продемонструвати, що вони дізналися i чому навчились, причому у привабливій для них формі, тобто презентувати значущі для студентів результати дисципліни чи окремої теми (Кузьминська, 2016: 88-89). Так, О. Кузьминською зроблено психологічний аналіз технології

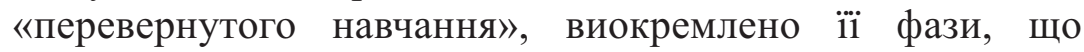
передбачають мотивацію, цілепокладання діяльності студентів, їх залучення до дослідження окремих проблем, усвідомлення результатів власної роботи на основі рефлексії та їх презентацію. 
Дж. Бергманн (J.Bergmann) i A. Самс (A. Sams) деталізують структуру аудиторного заняття з використанням технології «перевернутого навчання» та пропонують такі його складові: «розігрів» (вступ до теми) - 5 хвилин, питання стосовно відео - 10 хвилин, самостійна практична робота 75 хвилин (Bergmann J., Sams A., 2012: 15). Отже, науковці виділяють три основні етапи проведення «перевернутого навчання», що базуються на актуалізації знань студентів, проблемних запитаннях та уточненні основних теоретичних положень, практичній діяльності. Останній етап $\epsilon$ найбільшим та передбачає співпрацю студентів та практичне застосування отриманих знань.

Погоджуємося з Н. Приходькіною, що не існує єдиної моделі «переверненого навчання» - термін широко використовується для опису структури практично будь-яких занять, які будуються на перегляді попередньо записаних лекцій 3 наступним їхнім обговоренням безпосередньо в аудиторії (Приходькіна, 2014: 143). Однак, для ефективної реалізації «перевернутого навчання» використовуються певні цикли (фази), серед яких виділяється фаза перегляду навчального відео; фаза інтерактивної роботи; фаза усвідомлення результату; фаза зворотного зв'язку та ін. Кожен етап вимагає активної діяльності не тільки студентів, але й викладачів щодо розробки додаткових навчальних або контрольно-вимірювальних матеріалів для занять.

«Перевернуте навчання» як сучасна технологія має як позитивні сторони, так i певні труднощі у процесі їi застосування. С. Попадюк, М. Скуратівська визначають наступні переваги технології «перевернутого навчання» для студентів і викладачів, а саме:

- грунтовне «привласнення», тобто опанування нового матеріалу здійснюється незалежно від аудиторної присутності студента. Якщо студент i пропустив заняття, то він може все одно вивчити матеріал вдома;

- студенти можуть визначати свій темп та стратегії навчання, за потреби зупинити запис, повторити його або відразу ж знайти в Інтернеті чи в посібниках додаткову інформацію, потрібне роз'яснення. Таким 
чином може бути врівноважений неоднорідний попередній обсяг знань студентів;

- викладачі відкривають для себе нові можливості для організації аудиторної фази роботи як студентоорієнтованої, можуть детальніше розглядати проблеми, що виникли у студентів під час засвоєння матеріалу, можуть надати заняттю більшої інтерактивності (Попадюк, Скуратівська, 2017: 151).

- Перевагами застосування «перевернутого навчання» X. Маршалл (H. Marshall) вважає, по-перше, що воно сприяє кращому розумінню матеріалу, підвищує взаємодію 3 викладачем та іншими студентами, розвиває критичне мислення і робить його природною частиною процесу навчання. По-друге, при застосуванні цієї технології навчання аудиторний час витрачається раціональніше (Marshall, 2013). Отже, науковці єдині у поглядах на інноваційність та необхідність використання «перевернутого навчання» як технології інтенсивного навчання у практиці роботи вищої школи.

Ряд науковців (Н. Антонова, А. Меренков, С. Попадюк, M. Скуратівська, A. Roehl, L. Reddy, G. Shannon) відзначають i недоліки та труднощі впровадження технології «перевернутого навчання» у практику роботи вищої школи, серед яких дослідники виділяють низьку готовність студентів до перегляду матеріалів, розроблених викладачами; незвичність для студентів такої технології підготовки до лекції, необхідність певної адаптації до неї; невисоку технічну підготовленість самих викладачів, що перешкоджає якісному оформленню та презентації розроблених лекцій.

Вважаємо, що вищезазначені недоліки легко вирішуються в довгостроковій перспективі, а саме: готовність студентів до перегляду матеріалів залежить в більшості від якості та доступності викладеного матеріалу, а постійно зростаюча комп'ютерна на інформаційна грамотність сприяє покращенню цих показників; аналогічно, багаторазове застосування технології «перевернутого навчання» сприяє адаптації до неї студентів та підвищенню комп'ютерної грамотності викладачів. Н. Антонова та 
А. Меренков, досліджуючи особливості використання моделі «перевернутого навчання» у вищій школі, доводять, що, поперше, студентська спільнота набуває навичок самостійної роботи і планування свого часу лише до четвертого року навчання. Відповідно тільки до закінчення вишу студент стає найбільш підготовленим до включення в модель «перевернутого навчання»; по-друге, рівень обізнаності про модель «перевернутого освіти» у викладачів поки низький, i вони рідко роблять спроби застосовувати іiі на практиці, вважаючи за краще використовувати традиційні методи навчання. До числа перешкод (бар’єрів) в реалізації цієї новації ці автори також відносять відсутність часу у професорсько-викладацького складу для підготовки лекційних матеріалів у форматі відео-лекцій і необхідність у технічному супроводі «перевернутого навчання» (Антонова, Меренков, 2018: 243).

Враховуючи особливості «перевернутого навчання» у вищій школі (дочільність його використання на стариих курсах; низький рівень обізнаності про цүю технологію; брак часу та необхідність певної адаптації до ї̈ застосування; невисока технічна підготовленість викладачів до «перевернутого навчання») ця технологія у практиці роботи ДВНЗ «Переяслав-Хмельницький державний педагогічний університет імені Григорія Сковороди» застосовувалася у процесі організації навчання студентів-магістрантів при викладанні курсу «Педагогіка вищої школи». У нагоді стали матеріали авторського підручника (Шапран, Новак, 2018), який пропонувався студентам в електронному форматі. До лекційного матеріалу додавалися відео-презентації, завдання для самостійної роботи студентів, додаткові посилання на освітні електронні сайти і блоги. Особлива увага при застосуванні технології «перевернутого навчання» приділялася інтерактивній взаємодії учасників освітнього процесу при обговоренні основних питань лекційного матеріалу, залученні їх до роботи у різних проектах, виконанні ситуаційних вправ, пошуку найбільш ефективних методів і прийомів вирішення конкретних педагогічних проблем. Також проводилася i активна робота щодо 
ознайомлення викладачів з новітніми технологіями навчання. Згідно Наказу № 222 ДВНЗ «Переяслав-Хмельницький державний педагогічний університет імені Григорія Сковороди» від 20.11.2018 р. «Про впровадження інноваційних технологій i методик викладання» в університеті ініційовано проведення серії семінарів для професорсько-викладацького складу університету щодо можливостей використання інструментарію навчального середовища MOODLE. Для цього навчально-методичною радою університету розроблено та проведено серію семінарів для викладачів на теми: «Мобільне навчання», «Інтегроване навчання», «Змішане навчання», «Технологія «перевернутого навчання»«, «Дуальна освіта», «IBL (Inquiry Based Learning) - дослідницьке навчання), PBL (Project Based Learning - метод проектів) тощо.

\section{Висновки}

Отже, «перевернуте навчання» $є$ сучасною технологією, що спирається на ідеї активного навчання, залучення студентів до спільної діяльності, комбінованої системи навчання. Сутність цієї технології полягає у самостійному ознайомленні студентів з новим матеріалом у домашніх умовах на основі відео-лекцій, презентацій, а в процесі аудиторної роботи відбувається обговорення проблемних питань, закріплення теоретичних знань i вироблення практичних навичок. Така робота дозволяє студентам визначати власний темп навчання, виробляти індивідуальні стратегії роботи 3 навчальним матеріалом, перевіряти свої знання і взаємодіяти між собою в інтерактивному режимі.

Для ефективної реалізації «перевернутого навчання» використовуються певні цикли (фази), серед яких виділяється фаза перегляду навчального відео; фаза інтерактивної роботи; фаза усвідомлення результату; фаза зворотного зв'язку та ін. Кожен етап вимагає активної діяльності не тільки студентів, але й викладачів щодо розробки додаткових навчальних або контрольновимірювальних матеріалів для занять. 
На основі аналізу переваг та труднощів «перевернутого навчання» у закладах вищої освіти визначено особливості його застосування у вищій школі (доиільність використання на старших курсах; низький рівень обізнаності студентів $i$ викладачів про иңю технологію; брак часу на використання технології та необхідність певної адаптації учасників освітнього процесу до ї̈ застосування; невисока технічна підготовленість викладачів до «перевернутого навчання»).

Перспективи подальших розвідок вбачаємо у напрямку розробки відео-лекцій та програмного забезпечення «перевернутого навчання» для студентів різних спеціальностей.

\section{Література}

1. Антонова Н. Л., Меренков А. В. Модель «перевернутого обучения» в системе высшей школы: проблемы и противоречия. Интеграция образования. 2018. Вып. 22.T. 2. С. 237-247.

2. Байда М. В. Використання класичних технологій кооперативного навчання на змішаних та перевернутих заняттях у процесі фахової підготовки вчителівфілологів. Вісник Житомирського державного університету. Сер: Педагогічні науки . 2015. Вип. 4 (82). С. 83-87.

3. Кадемія М. Ю. Інформаційно-комунікаційні технології у перевернутому навчанні студентів. Звітна наукова конференція Інституту інформаційних технологій $i$ засобів навчання НАПН Украӥни: зб. матер. наук. конф. (м. Київ, 28 берез. 2017 р.). Київ : IIТЗН НАПН України, 2017. С. 147-150.

4. Кузьмінська О. Г. Перевернуте навчання: практичний аспект. Інформаціийні технологї в освіті. 2016. № 1 (26). С. 86-98.

5. Попадюк С. С., Скуратівська М. О. Методологічні засади використання освітньої концепції «перевернуте навчання» у вищій школі. 3б. наук. пращзь Херсон пед. ун-ту. Педагогічні науки. 2017. Вип. LXXVI. Т. 3. C. 149-154. 
6. Приходькіна Н. О. Використання технології «переверненого навчання» у професійній діяльності викладачів вищої школи. Науковий вісник Уэггород. нац.. ун-ту. Сер.: Педагогіка, соціальна робота. 2014. Вип. 30. С. 141-144.

7. Харламова Т.В. Перевернутое обучение как новый сценарий обучения. Иностранные языки в контексте межкультурной коммуникации: матер. докладов VI Международ. Интернет-конф. (г. Саратов, 26-28 февраля 2014 г.). Саратов, 2014. С. 312-317. URL: http://www.sgu.ru/sites/default/files/textdocsfiles/2015/02/ 18/harlamova_t.v._perevernutoe_obuchenie_pf.pdf

8. Bergmann, J., \& Sams, A. (2015). Flip Your Classroom: Reach Every Student in Every Class Every Day. Washington DC: International Society for Technology in Education. 120 p.

9. Roehl, A., Reddy, L.S. \& Shannon, G.J. (2013). The flipped classroom: An opportunity to engage millennial students through active learning strategies. Journal of Family and Consumer Sciences. Vol. 105, no. 2. Pp. 44-49. URL: http://eric.ed.gov/?id=EJ1045858

10. Marshall, H. (2013). Three reasons to flip your classroom. Bilingual Basics.

URL: http://newsmanagercommpartnerscom tesolbeis

11. Sharples, M., Adams, A., Ferguson, R., Gaved, M., McAndrew, P., Rienties, B., Weller, M., \& Whitelock, D. (2014). Innovating Pedagogy 2014: Open University Innovation Report 3. Milton Keynes: The Open University.

\section{Шапран О. І., Шапран О. Ю.}

Особливості

застосування

технології «перевернутого навчання» у закладах вищої освіти

\section{Анотація}

У статті охарактеризовано застосування технології «перевернутого навчання» у практиці роботи закладів вищої 
освіти. Доведено, що для ефективної реалізації «перевернутого навчання» використовуються певні цикли (фази), серед яких виділяється фаза перегляду навчального відео; фаза інтерактивної роботи; фаза усвідомлення результату; фаза зворотного зв'язку та ін.

Авторами проаналізовані переваги та труднощі застосування «перевернутого навчання» у закладах вищої освіти. У статті визначені особливості «перевернутого навчання» у вищій школі (доцільність його використання на старших курсах; низький рівень обізнаності про иүю технологію; брак часу та необхідність певної адаптації до ii застосування; невисока технічна підготовленість викладачів до «перевернутого навчання») та описано досвід використання цієї технології у практиці викладання курсу «Педагогіка вищої школи» для студентів-магістрантів ДВНЗ «Переяслав-Хмельницький державний педагогічний університет імені Григорія Сковороди».

Ключові слова: «перевернуте навчання», змішане навчання, відео-лекції, коучинг, навчальні ігри, електронне середовище.

\section{Шапран О. И., Шапран А. Ю.}

\section{Особенности \\ использования \\ технологии «перевернутого обучения» в учреждениях высшего образования}

\section{Аннотация}

В статье охарактеризовано применение технологии «перевернутого обучения» в практике работы высших учебных заведений. Доказано, что для эффективной реализации «перевернутого обучения» используются определенные циклы (фазы), среди которых выделяется фаза просмотра обучающего видео; фаза интерактивной работы; фаза осознание результата; фаза обратной связи и др.

Авторами проанализированы преимущества и трудности применения «перевернутого обучения» в учреждениях высшего образования. В статье определены 
особенности «перевернутого обучения» в высшей школе (целесообразность его использования на старших курсах, низкий уровень осведомленности об этой технологии; нехватка времени и необходимость определенной адаптации к ее применению; невысокая техническая подготовленность преподавателей к «перевернутого обучения») и описан опыт использования этой технологии в практике преподавания курса «Педагогика высшей школы» для студентовмагистрантов ДВНЗ «Переяслав-Хмельницкий государственный педагогический университет имени Григория Сковороды».

Ключевые слова: «перевернутое обучение», смешанное обучение, видео-лекции, коучинг, обучающие игры, электронная среда. 